\title{
Kemampuan pemahaman membaca teks dan komunikasi matematik sebagai landasan dalam pemecahan masalah
}

\author{
Neneng Maryani \\ Prodi PGMI IAILM, Tasikmalaya, Indonesia \\ nenengmaryani93@gmail.com
}

\begin{abstract}
ABSTRAK
Artikel ini merupakan reviu artikel hasil penelitian internasional yang secara spesifik lebih menekankan pada pembahasan mengenai kemampuan pemahaman membaca teks matematik dan komunikasi matematik sebagai landasan dalam pemecahan masalah. Adapun uraian secara rinci antara lain mengenai kriteria pemahaman dalam membaca suatu teks matematik; efektivitas program berbasis bahasa dalam matematika sekolah terhadap pemahaman siswa; penggunaan pendekatan dan media pembelajaran dalam membangun pemahaman konsep dan komunikasi dalam pemecahan masalah matematik; serta strategi membangun komunikasi matematik.
\end{abstract}

Kata-kata Kunci: Pemahaman Matematik; Komunikasi Matematik; Pemecahan Masalah Matematik;

\section{Reading comprehension ability and mathematical communication as a foundation in problem solving}

\begin{abstract}
This article is a review of international research articles that specifically emphasize the discussion of the ability to read mathematical texts and communicate mathematics as a basis for problem solving. The detailed descriptions include the criteria for understanding in reading a mathematical text; the effectiveness of language-based programs in school mathematics on student understanding; the use of learning approaches and media in building conceptual understanding and communication in solving mathematical problems; and strategies to build mathematical communication.
\end{abstract}

Keywords: Mathematical Comprehension; Mathematical Communication; Mathematical Problem Solving

\section{PENDAHULUAN}

Matematika adalah sesuatu yang luar biasa yang mampu membangkitkan minat, memberi keceriaan, penuh kompleksitas, membuat prustrasi, menakutkan, dan disiplin ilmu yang penuh dengan misteri bagi sebagian peserta didik. Terkadang mereka berpikir bahwa matematika hanya melibatkan angka dan simbol yang abstrak. Mereka melupakan bahwa matematika juga melibatkan pikiran dan bahasa yang memiliki sejumlah aturan dan istilah. Dengan demikian perlu adanya pemahaman terhadap suatu teks matematik melalui peningkatan kemampuan membaca secara bermakna (memahami). Fuentes (1998) mengatakan bahwa mengembangkan kemampuan membaca dan keterampilan matematik peserta didik sangat penting untuk direalisasikan oleh guru, sebab mereka cenderung lebih mengembangkan keterampilan prosedural dalam matematika sehingga kesulitan memahami istilah atau bacaan dari teks untuk memecahkan masalah matematik 
Ketika berbicara tentang membaca, hal ini jelas sering dilakukan untuk memecahkan masalah, sebagai contoh, memeriksa istilah masalah atau mempelajari ekspresi simbolis. Memeriksa istilah dalam pemecahan masalah adalah salah satu tugas yang paling menantang dalam matematika bagi kebanyakan siswa. Ini mengharuskan solver untuk menerjemahkan masalah ke dalam bahasa matematik. Dari hasil studi penelitian yang dilakukan oleh Ahmad, Siti \& Roziati (2008) terhadap peserta didik sekolah menengah di Malaysia ditemukan bahwa mayoritas dari mereka tidak menuliskan solusi masalah dengan menggunakan bahasa matematik yang benar. Dengan demikian komunikasi intrapersonal dan interpersonal penting dalam belajar matematika terutama dalam menginterpretasikan istilah untuk memecahkan masalah matematika.

Dalam penelitiannya tersebut, Ahmad, Siti \& Roziati menyajikan sebuah model pembelajaran yaitu Komunikasi Kognitif (Cognitive-Communication) yang mempromosikan penggunaan bahasa matematik. Model ini digunakan sebagai dasar dalam desain pembelajaran berbasis komputer untuk memecahkan masalah. Alat yang digunakan dikenal dengan istilah MINDA yang menggabungkan beberapa langkah penting yang diperlukan dan kegiatan tersebut dikembangkan untuk memfasilitasi pembelajaran. MINDA terdiri dari dua sistem utama yaitu Word Problem Lab (WPL) dan Learning Courseware (LEARN). Modul MINDA mencakup sumber pemecahan dan alatalat belajar seperti alat refleksi, kalkulator / konverter pecahan, kamus matematik dan alat visualisasi.

Pemecahan masalah merupakan aspek utama dari matematika dan penelitian pendidikan matematika. Minimnya kemampuan peserta didik memahami istilah matematik sehingga sulit mengkomunikasikan dengan menerjemahkan masalah ke dalam bahasa matematik dalam proses pemecahan masalah memiliki keterkaitan dengan pemahaman membaca. Namun, dalam memecahakan masalah matematik, belum cukup hanya ditopang oleh kemampuan matematik khususnya pemahaman dan komunikasi, tetapi dipengaruhi pula oleh faktor lain, diantaranya adalah disposisi matematik siswa khususnya sistem kepercayaan dan motivasi.

Sebagaimana dikemukakan oleh Luz Maria \& Antoni Vila (2009), bahwa terdapat dua aspek yang menjelaskan pendekatan para siswa dalam proses pemecahan masalah yaitu dualistik sistem kepercayaan yang berasal dari pengalaman sekolah siswa; dan motivasi yang berhubungan dengan kepercayaan tentang kesulitan tugas. Dari hasil temuan Luz Maria \& Antoni Vila (2009), terdapat hubungan yang kompleks antara sistem kepercayaan siswa dengan pendekatan dalam proses pemecahan masalah matematik jika memperhitungkan berbagai kepercayaan seputar hakikat matematika dan pemecahan masalah serta kepercayaan tentang motivasi, tetapi tidak mungkin untuk membangun hubungan sebab akibat antara kepercayaan tertentu dengan aktivitas pemecahan masalah (atau sebaliknya). 
Dalam artikel ini, pembahasan dibatasi pada tinjauan kemampuan matematik khususnya kemampuan pemahaman membaca teks dan komunikasi matematik yang harus dilatih dan dikembangkan sebagai penopang dalam memecahkan masalah matematika. Dengan demikian, judul artikel ini adalah Kemampuan Pemahaman Membaca Teks dan Komunikasi Matematik sebagai Landasan dalam Pemecahan Masalah..

\section{HASIL DAN PEMBAHASAN}

\section{Kriteria Pemahaman dalam Membaca Suatu Teks Matematik}

Kriteria pemahaman yang digunakan dalam membaca suatu teks matematik menurut Baker (Osterholm, 2006) meliputi:

Leksikal : Kata

Sintaksis : Tata Bahasa

Kriteria Semantik:

Proposisional : Integrasi ide dalam teks (misalnya, ketika salah satu teks merupakan bagian dari teks yang lain)

Struktural : Mendukung gagasan tematis dalam teks (misalnya, jika bagian dari teks disesuaikan dengan tema utama dari teks)

Eksternal : Konsisten dengan pengetahuan sebelumnya

Internal $\quad$ Konsisten terhadap ide dalam teks (misalnya, terdapat dua bagian dari teks yang tidak kontradiksi satu sama lain)

Kejelasan : Informasi yang dibutuhkan untuk mencapai tujuan tertentu.

Berdasarkan hasil temuan Osterholm (2006) dalam penelitian studi kasus terhadap mahasiswa Universitas Linkoping, Swedia, menunjukkan bahwa responden tampaknya kesulitan mengartikulasikan alasan mereka dalam memahami suatu bacaan. Ketika mereka diminta mengemukakan alasan logis atas pemahaman mereka, responden kadang-kadang haya tertuju pada bagian kecil dari teks, menyatakan bahwa bagian ini tidak mengerti, tetapi tidak memberikan alasan atas pernyataannya tersebut. Selain itu, terkadang mereka nampak gelisah dengan situasi tersebut.

Dalam penelitiannya, Osterholm menemukan bahwa tidak terdapat perbedaan kriteria yang digunakan untuk makro dan mikrostruktur dalam teks, tetapi perbedaan kriteria khususnya kriteria eksternal ditemukan dalam teks konseptual dan teks prosedural. Kriteria eksternal banyak dipakai dalam teks konseptual tetapi sulit dipakai dalam teks prosedural, sehingga perlu adanya perbaikan dan penjelasan kategori dari kriteria sintaksis baik kategori konseptual (bahasa asli) dan kategori prosedural (bahasa simbolis). 


\section{Efektivitas Program Berbasis Bahasa dalam Matematika Sekolah terhadap Pemahaman} Siswa

Berbeda dengan Osterholm, Wasike (2006) mengemukakan bahwa kemampuan pemahaman dipengaruhi oleh adanya penerapan Program Berbasis Bahasa yang dikenal dengan istilah Socialized Mathematical Language (SML). Dari hasil penelitian kuasi eksperimennya tersebut terhadap siswa sekolah menengah di daerah Bungoma, Propinsi bagian barat Kenya menunjukkan bahawa Program Berbasis Bahasa efektif untuk meningkatkan pengetahuan (pemahaman) dan keterampilan siswa juga persepsi (pandangan) mereka terhadap lingkungan belajarnya. Disamping itu, efektivitas Program Berbasis Bahasa mampu meningkatkan kemampuan kognitif dan apektif dalam matematika.

SML adalah program yang mampu menyederhanakan dan menjelaskan symbol dan struktur bahasa khusus dalam matematika. Program ini mampu mendeskripsikan makna dari istilah teknis dalam matematika jika dibandingkan dengan makna dalam Bahasa Inggris. Program seperti itu mungkin digunakan dalam setting pembelajaran matematika yang disediakan. Adapun kemampuan pemahaman yang dimaksud dalam penelitian Wasike antara lain pemahaman relasional yaitu kemampuan memahami serta mengaitkan simbol dengan struktur bahasa khusus yang digunakan dalam matematika terutama statistika serta mampu membandingkannya dengan makna asli dari Bahasa Inggris. Oleh karena itu, diperlukan pengabungan model-model bahasa dalam pembelajaran matematika.

\section{Penggunaan Pendekatan dan Media Pembelajaran dalam Membangun Pemahaman} Konsep dan Komunikasi dalam Pemecahan Masalah Matematik

Lain halnya dengan Serhan (Tanpa Tahun), meskipun melakukan penelitian eksperimen terhadap objek dengan level yang sama seperti Osterholm yakni level Universitas, namun diperoleh hasil temuan yang berbeda berkaitan dengan pemahaman. Menurut Serhan, kemampuan pemahaman matematik peserta didik dipengaruhi oleh penggunaan peta konsep berbasis bantuan media kalkulator. Studi ini meneliti pengaruh penggunaan kalkulator grafik terhadap pemahaman mahasiswa tentang turunan di suatu titik. Studi ini juga melihat perbedaan antara gambar konsep yang dimiliki oleh mahasiswa yang menggunakan kalkulator grafik dengan mahasiswa yang tidak menggunakan kalkulator grafik, serta membandingkan antara penggunaan peta konsep pada gambar konsep mahasiswa dengan peta konsep seorang ahli. 
Dari hasil temuannya menunjukkan bahwa mahasiswa yang menggunakan peta konsep berbasis bantuan media kalkulator grafik mampu menyebutkan representasi konsep lebih banyak dibandingkan dengan mahasiswa yang menggunakan peta konsep tanpa bantuan media kalkulator grafik. Hal ini menunjukkan bahwa mahasiswa yang menggunakan peta konsep berbasis bantuan media kalkulator grafik memiliki gambaran (pemahaman) konsep derivatif pada suatu titik yang lebih baik dibandingkan dengan mahasiswa yang menggunakan peta konsep tanpa bantuan media kalkulator grafik. Mahasiswa yang menggunakan peta konsep berbasis bantuan media kalkulator grafik memiliki kesempatan untuk melihat konsep derivatif menggunakan representasi yang berbeda, dan gambar visual ditekankan melalui penggunaan teknologi grafik kalkulator. Lingkungan belajar ini dapat mempengaruhi pemahaman dan komunikasi mahasiswa.

Pemahaman konsep dan kemampuan prosedural merupakan indikator pemahaman yang dimaksud dalam penelitian Serhan, sedangkan kemampuan representasi simbolik dan gambar visual merupakan indikator dari kemampuan komunikasi dalam matematika.

Selain dengan penggunaan peta konsep berbasis bantuan media kalkulator, untuk meningkatkan kemampuan pemahaman berupa pengetahuan matematik khususnya penalaran metakognitif dapat pula digunakan metode lain dalam kegiatan pembelajarannya, diantaranya adalah metode pembelajaran metakognitif yang lebih dikenal dengan istilah Metode IMPROVE (Introducing the new concepts, Meta-cognitive questioning, Practicing, Reviewing, Obtaining mastery, Verification, and Enrichment and remedial).

Dalam metode tersebut, pertamakali guru mengenalkan konsep baru, teorema, rumus, dan sebagainya kepada siswa dengan memodelkan teknik pertanyaan metakognitif. Diawal pembelajaran, siswa diujicoba menggunakan tiga jenis pertanyaan metakognitif yaitu: pertanyaan pemahaman, pertanyaan pengaitan (koneksi), dan pertanyaan strategi. Kemudian jenis pertanyaan metakognitif keempat ditambahkan yaitu pertanyaan refleksi. Pertanyaan pemahaman, mengorientasikan siswa untuk mengartikulasikan ide-ide utama dalam masalah (Misal, masalahnya tentang apa?). Pertanyaan pengaitan (koneksi), mengarahkan siswa untuk menyusun penghubung antara masalah yang diberikan dengan masalah yang telah dipecahkan (Misal, apa persamaan dan perbedaan antara masalah yang diberikan dengan masalah yang telah dipecahkan sebelumnya, dan mengapa?). Pertanyaan strategi mengacu pada strategi yang tepat untuk memecahkan masalah (Misal, strategi apa yang tepat untuk memecahkan masalah, dan mengapa?). Pertanyaan refleksi memandu siswa untuk melihat kembali ke belakang selama proses solusi (Misal, mengapa saya terjebak?, Apa yang saya kerjakan di sini?) atau (Misal, apakah solusi ini masuk akal? Apakah saya dapat menyelesaikan perbedaan itu?). 
Sebagaimana hasil temuan Mevarech \& Shimon (2006) dalam penelitian eksperimennya terhadap calon mahasiswa pendidikan matematika di Israel yang sedang mengikuti matrikulasi menunjukkan bahwa mahasiswa yang memperoleh Metode IMPROVE mengungguli rekan-rekan mereka yang memperoleh pembelajaran tradisional baik dalam hal pengetahuan matematik maupun penalaran matematik. Selain itu, mahasiswa yang memperoleh Metode IMPROVE secara signifikan memiliki skor yang lebih tinggi dari mahasiswa yang memperoleh pembelajaran tradisional dalam tiga penilaian metakognisi yaitu kognisi pengetahuan umum, kognisi pengaturan umum, dan domain khusus dari pengetahuan metakognisi.

Flavell (Mevarech \& Shimon, 2006) mendefinisikan metakognisi sebagai "thinking about thinking”, yang dibedakan atas dua komponen yaitu pengetahuan tentang proses kognitif dan hasil kognitif dan kemampuan mengawasi, memonitor, mengevaluasi proses kognitif. Pengetahuan tentang kognisi tergantung pada komponen yang saling terkait sebagai berikut: pengetahuan metakognitif tentang diri, tugas dan strategi; pengetahuan tentang bagaimana menggunakan strategi, dan pengalaman metakognitif. Kemudian merujuk pada perasaan seseorang tentang menjadi sukses (atau gagal) dalam menjalankan tugas. Menurut model ini, pengetahuan metakognitif diarahkan untuk menggunakan strategi yang pada gilirannya mempengaruhi pengalaman metakognitif yang mempengaruhi perolehan pengetahuan metakognitif dan sebagainya.

Adapun yang dimaksud pengetahuan metakognitif dalam penelitian Mevarech \& Shimon adalah pengetahuan metakognisi umum dan domain khusus. Pengetahuan metakognisi umum diadopsi dari Schraw \& Dennison (Mevarech \& Shimon, 2006) yang dibedakan atas dua jenis, yaitu kognisi pengetahuan dan kognisi regulasi. Kognisi pengetahuan mengacu pada pengetahuan deklaratif, prosedural dan kondisional. Pengetahuan declaratif mengacu pada pengetahuan tentang kemampuan seseorang, sumber daya intelektual, dan kemampuan sebagai seorang pembelajar. Pengetahuan prosedural mengacu pada pengetahuan tentang bagaimana menerapkan prosedur pembelajaran (misalnya, strategi). Pengetahuan kondisonal mengacu pengetahuan tentang kapan dan mengapa menggunakan prosedur belajar. Kognisi regulasi meliputi perencanaan, pengelolaan informasi, pemantauan, debugging, dan evaluasi. Definisi operasional dari kategori ini menurut Schraw \& Dennison adalah sebagai berikut: Planning: perencanaan, penetapan tujuan, dan mengalokasikan sumber daya sebelum belajar; Informasi manajemen: keterampilan dan urutan strategi yang digunakan secara online untuk proses informasi yang lebih efisien; Monitoring: penilaian tujuan pembelajaran atau penggunaan strategi; Debugging: strategi yang digunakan untuk mengoreksi kesalahan pemahaman dan kinerja; Evaluasi: analisis kinerja dan efektivitas strategi setelah belajar. 
Pengetahuan metakognisi domain khusus diadopsi dari Montague \& Bos (Mevarech \& Shimon, 2006) yang menilai proses metamatematik dengan mengidentifikasi proses metakognisi sebelum, selama dan setelah menyelesaikan masalah matematika. Adapun indikator pengetahuan dan penalaran matematik yang digunakan dalam pemecahan masalah dalam penelitian tersebut meliputi: menyelesaikan masalah dan menentukan semua langkah solusi, serta membuktikan kebenaran dari suatu proposisi dan menjelaskan alasannya secara tertulis.

Berikut ini diberikan contoh instrumen tes yang digunakan oleh Mevarech \& Shimon (2006) untuk mengukur kemampuan pengetahuan dan penalaran dalam pemecahan masalah:

Bagian 1 : Masalah Optimum

Suatu jual beli dikatakan baik apabila berhasil menjual 355 NIS dalam sehari. Hari pertama terjual 1 NIS, hari kedua terjual 2 NIS, hari ketiga terjual 4 NIS, dll. Setelah berapa hari penjual memperoleh keuntungan maksimum? Mohon jelaskan semua tahap solusi termasuk perhitungannya, dan jelaskan alasan anda!

Bagian 2 : Kebenaran Proposisi Matematika

Dari semua segitiga dengan keliling p, maka segitiga sama sisi memiliki luas daerah terbesar. Buktikan kebenaran proposisi tersebut!

\section{Strategi Membangun Komunikasi Matematik}

Berdasarkan hasil temuan Clark, dkk., (2005), untuk membangun komunikasi siswa khususnya siswa sekolah menengah secara efektif baik melalui lisan maupun tulisan, terdapat beberapa strategi khusus yang dapat dilakukan guru diantaranya: (1) sikap yang kaya dengan tugas, (2) menciptakan lingkungan yang aman, (3) bertanya pada siswa untuk menjelaskan dan membuktikan kebenaran solusi, (4) proses secara aktif antar idea. Selain membangun komunikasi siswa secara efektif, strategi yang dikembangkan oleh Clark, dkk., mampu menciptakan komunitas diskursus matematik, dimana siswa bebas mengekspresikan pemikiran mereka, dan bertanggung jawab untuk mendengar, menafsirkan, membuat pertanyaan, dan menginterpretasikan ide secara utuh dalam kelas secara keseluruhan maupun dalam diskusi kelompok kecil.

Berikut ini contoh bahan ajar yang digunakan Clark, dkk., untuk membangun komunikasi matematik siswa dan menciptakan komunitas diskursus:

\section{Bahan Ajar: Masalah "Painted Cubes"}

Sebuah kubus dengan panjang sisi $2 \mathrm{~cm}$ dibangun dari kubus satuan. Jika kamu mengecat permukaan kubus ini dan kemudian berhenti pada kubus satuan, berapa banyak kubus yang akan dicat pada tiga permukaan? Berapa banyak kubus yang akan dicat pada dua permukaan? Berapa 
banyak kubus yang akan dicat pada satu permukaan? Apa akibatnya jika sisi kubus mempunyai panjang berbeda dari dua? Apa akibatnya jika panjang sisi kubus $3 \mathrm{~cm}$ ? $50 \mathrm{~cm}$ ? $\mathrm{n} \mathrm{cm}$ ?

\section{SIMPULAN}

Berdasarkan temuan hasil penelitian internasional sebagaimana telah diuraikan pada bagian pembahasan, maka kesimpulan yang dapat dirumuskan penulis dalam artikel ini antara lain: 1). Untuk memecahkan masalah matematika tidak cukup dengan mengembangkan kemampuan prosedural, tetapi perlu ditopang oleh kemampuan pemahaman membaca teks yang mumpuni dan komunikasi matematik yang jelas sehingga dapat memeriksa istilah dan mempelajari ekspresi simbolis untuk diterjemahkan dan dituliskan dalam bahasa matematik yang benar; 2). Untuk menyederhanakan dan menjelaskan simbol dan struktur bahasa khusus dalam matematika dapat memanfaatkan suatu program berbasis bahasa yang dikenal dengan istilah SML sehingga siswa mampu memahami serta mengaitkan simbol dengan struktur bahasa khusus yang digunakan dalam matematika; 3). Untuk mengembangkan kemapuan pemahaman dan komunikasi dalam memecahkan masalah matematika dapat digunakan berbagai pendekatan serta media pembelajaran yang efektif. Beberapa diantaranya melalui pembelajaran peta konsep untuk memahami konsep, merepresentasikan simbol dan gambar visual; metode IMPROVE untuk mengembangkan pemahaman tentang pengetahuan metakognitif; 4). Untuk membangun komunikasi matematik siswa, diperlukan kreatifitas guru dalam memilih strategi yang efektif dan efisien yang mendorong terciptanya komunitas diskursus matematik.

\section{DAFTAR PUSTAKA}

Ahmad, A., Siti S.S., dan Roziati Z. (2008). A Cognitive Tool to Support Mathematical Communication in Fraction Word Problem Solving. Vol. 7, pp. 228-236. Wseas Transactions on Computers, ISSN: 1109-2750.

Clark, dkk. (2005). Strategies for Building Mathematical Communication in the Middle School Classroom: Modeled in Professional Development, Implemented in the Classroom. Current Issues in Middle Level Education (CIMLE), 11 (2), 1-1 2.

Fuentes, P. (1998). Reading Comprehension in Mathematics. p.81(8). Gale Arts, Humanities and Education Standard Package.

Luz, M. C., \& Antoni V. (2009). Approach to mathematical problem solving and students'belief systems: two case studies. Springer Science + Business Media, Inc.

Mevarech, Z., \& Shimon F. (2006). Metacognition Learning. 1: 85-97. Springer Science + Business Media, Inc. Osterholm, M. (2006). Metacognition And Reading - Criteria For Comprehension Of Mathematics Texts. In Novotná, J., Moraová, H., Krátká, M. \& Stehlíková, N. (Eds.). Proceedings 30th Conference of the International Group for the Psychology of Mathematics Education, Vol. 4, pp. 289-296. Prague: PME.

Serhan, D. (Tanpa Tahun). Using Concept Maps to Assess the Effect of Graphing Calculators Use on Students' Concept Images of the Derivative at a Point. Department of Mathematics, Arizona State University.

Wasike, D. W. (2006). Effectiveness of A Language Based Program in School Mathematics on Students Understanding of Statistics. Vol. 2, No. 3. Eurasia Journal of Mathematics, Science and Technology Education. 
Zemira Mevarech \& Shimon Fridkin. (2006). The effects of IMPROVE on mathematical knowledge, mathematical reasoning and meta-cognition. Metacontion Learning. 1: 85-97. Springer Science + Business Media, Inc. 